\title{
Four South African "sunrises", four cartoons, four eras and the cyclical nature of history
}

\section{Lizette Rabe*}

\begin{abstract}
History as having a cyclical nature has been accepted as theory since ancient times. According to this cyclical theory, events happen in recurring cycles, or, simply put, it is a matter of "history repeating itself". This article examines four cartoons as an illustration of history as cyclical phenomenon in one metaphor that was used in four political cartoons that were published over just more than a century in South Africa. All four cartoons depict the metaphor of "a new dawn" or a "new sunrise", although representing four different political eras in the country. As foundational point of departure, media history and media historiography is discussed, followed by cartoons and their development as editorial comment, after which follows a discussion of the use of metaphor in cartoons. The four cartoons, representing four political eras, are next presented, supplemented by brief biographies of the four cartoonists as further context. The cartoons, although representing different political eras in South Africa, are linked through the use of the sunrise metaphor, graphically illustrating history as being cyclical, or repeating itself. This article hopes to not only contribute to South African (media) history, but especially to stimulate cartoon studies, specifically from within a (media) historiographical framework.
\end{abstract}

Key words: African nationalism; Afrikaner nationalism; cartoons; colonialism; imperialism; history; media history; South Africa.

\section{Opsomming}

Geskiedenis as synde siklies van aard word sedert die antieke tye as teorie aanvaar. Volgens hierdie sikliese teorie van die geskiedenis vind gebeurtenisse in siklusse plaas - 'n geval van "die geskiedenis herhaal homself". Hierdie artikel ondersoek vier spotprente as so 'n illustrasie van die geskiedenis as 'n sikliese verskynsel, in een metafoor, wat gebruik is in vier politieke spotprente wat oor net meer as 'n eeu in Suid-Afrika gepubliseer is. Al vier spotprente toon die metafoor van 'n nuwe dagbreek of 'n "nuwe sonsopkoms", maar verteenwoordig vier verskillende politieke eras in die land se geskiedenis. As vertrekpunt word 'n bespreking van mediageskiedenis en mediahistoriografie aangebied. Spotprente en hul ontwikkeling as redaksionele

* $\quad$ Lizette Rabe is professor and chair of the Department of Journalism at Stellenbosch University. She can be contacted at lrabe@sun.ac.za.

How to cite this article: L. Rabe, "Four South African 'sunrises', four cartoons, four eras and the cyclical nature of history", Historia, 63, 1, May 2018, pp 178-200. 
kommentaar word bespreek, waarna 'n bespreking van die gebruik van metafoor in spotprente volg. Die vier spotprente, wat vier politieke eras verteenwoordig, word vervolgens aangebied, elk aangevul met 'n kort biografie van die spotprentkunstenaar as verdere konteks. Die spotprente verteenwoordig vier verskillende eras in SuidAfrika, met die metafoor van 'n nuwe dagbreek as grafiese illustrasie van die sikliese aard van geskiedenis. Hierdie artikel hoop om nie allen by te dra tot Suid-Afrikaanse (media)geskiedenis nie, maar ook om spotprentstudie te stimuleer, spesifiek vanuit 'n mediahistoriografiese raamwerk.

Sleutelwoorde: Afrika-nasionalisme; Afrikanernasionalisme; spotprente; kolonialisme; imperialisme; geskiedenis; mediageskiedenis; Suid-Afrika.

\section{Introduction}

This article endeavours to present, from a media historiographical point of view, four South African cartoons that applied the same metaphor, namely the depiction of a "new sunrise" for the country, in South African publications in four different political eras between 1906 and 2016. These four cartoons represent South Africa's colonial past as part of the British Empire (Figure 1); South Africa's apartheid past under Afrikaner nationalism's National Party (NP) rule (Figure 3); a democratic dispensation under the first African National Congress (ANC) government (Figure 6), and the era under the Zuma presidency (Figure 8).

Firstly, a discussion of media historiography is presented to provide context, because this understudied field of journalism and media studies needs to be supported and strengthened by a foundational theoretical exposition. This will be followed by a discussion of cartoons as part of the genre of commentary, or editorials, in news media, including an overview of the study of cartoons.

The use of metaphor in cartoons will be discussed next, because in this case, "a new dawn" or "a new sunrise", was used as metaphor for four eras "dawning" in South Africa. This will be followed by a presentation of the four cartoons in chronological order, including a discussion of their cartoonists as context to illustrate their relationship to their era and the resultant execution of the specific cartoon.

This article hopes to inspire more such studies in the field of media historiography, specifically to stimulate cartoon studies as source of history. The first cartoon discussed in this article, one by Arthur Lloyd, was published in 1906, in other words, five years after the end of the South African War (or Anglo-Boer War) and four years before the formation of the Union of South Africa in 1910. At the time the cartoon was published, South Africa comprised two British colonies (the Cape and Natal) and two former Boer republics (the Transvaal or former Zuid-Afrikaansche Republiek, and the Oranje-Vrystaat). The second cartoon, by T.O. Honiball, was published mid-century, in 1948, on the occasion of the victory of the National Party (NP); the third, by Zapiro, in 1994, on the occasion of the victory of the African National Congress and the "dawning" of the so-called new democracy; and the last, by Fred Mouton, on 2 January 2016, at the dawn of a new year. Since the first cartoon 
was published, South Africa has experienced different political systems. The first was a period of colonialism as part of the British Empire, until 1910; the second, from 1948, when the apartheid government came to power (including the 1961 declaration of a republic independent of the Commonwealth); and the third, the ANC victory in 1994.

\section{(Media) historiography: A brief foundational discussion}

Journalism history, or media history, as a focus in the field of journalism studies, or media studies, or communication studies, or communication science, ${ }^{1}$ is a relatively "recent phenomenon" in South Africa. ${ }^{2}$ This is confirmed by Wigston, who states it is a relatively understudied sub-discipline within journalism and media studies. ${ }^{3}$ Progressing from these observations, one can say that an even bigger lacuna exists in the study of cartoons from a media historiographical point of departure. Thus the purpose of this brief discussion of media historiography is, firstly, to serve as a foundation for this specific article, but also to add to and strengthen the position of media history and media historiography 4 as an underdeveloped focus in South African research. ${ }^{5}$

The approach in this article is decidedly a historiographical one, and not one based on semiotics, as the first approach to cartoons would suggest, namely to analyse the subject according to the tenets of semiotics. Another reason for this foundational discussion of locating this article within historiography is to add a theoretical layer to the discussion - that history, and thus also media history, find themselves in the nexus between the humanities and the social sciences, supporting the argument that history straddles the two disciplines. This article therefore also argues that historiography, and thus media historiography, as subfield of both media

1. Journalism studies, media studies, communication studies and communication science all focus on the study of communication - the first two specifically focusing on mass communication. This is stated merely as an acknowledgement of the fact that different approaches to the field exist. According to B. Franklin, M. Hamer, M. Hanna, M. Kinsey and J.E. Richardson, Key Concepts in Journalism Studies (Sage, London, 2005), p 143, journalism can be seen broadly as a field within mass communication that records the events of the day and disseminates content on any given news platform, be it in print, broadcast (radio or TV) or digital, mobile format. Journalism is a subfield of media, suggesting the "channel in and through which messages are communicated, whether by written, spoken or otherwise semiotic means".

2. S. Sonderling, "Historical Research in Communication", in G.M. du Plooy (ed.), Introduction to Communication (Juta, Cape Town, 1995), $\mathrm{p} 87$.

3. D. Wigston, "A History of South African Media", in P.J. Fourie (ed.), Media Studies, Media History, Media and Society (Juta, Cape Town, 2007), p 5.

4. The difference between history and historiography is understood as per the definitions by Woolf that history is the discipline of history as it has developed in the past two centuries, as the "accumulated events of the past", and can consist of many genres. Historiography is the writing of history, including the meta level of historical thinking, a study of how history has been written. See D. Woolf, A Global History of History (Cambridge University Press, New York, 2011), pp 2-5.

5. Wigston, "A History of South African Media", p 5. 
studies and history, draws on both the humanities and the social sciences, and that the traditional divide between the two is merely academic.

This tension in terms of the status of journalism/media studies, together with history, is based on the issue of whether they belong within the humanities or the social sciences, as was also discussed by Rabe who argues that historiography draws from both disciplines. ${ }^{6}$ As it is a seemingly ongoing contestation, a brief rationale is provided. The different views about the nature and aim of historical research distinguish between these two main approaches with, on the one hand, the humanist/positivist (or idiographic [particularising]) (thus from within the humanities) approach, and on the other, a scientific/idealist (or nomothetic [generalising]) (thus from within the social sciences) approach. But, as Nord argues, it is a "very bad" controversy, although well into its second century, with the "distinction ... necessarily blurred". The typologies are in fact "really continuous variables". In practice, according to Nord, "historians have never been completely idiographic, nor can they ever be completely nomothetic" and move back and forth from the particular to the general. ${ }^{7}$

This distinction between a humanities approach and a social sciences approach is also typologised by Brennen as being the difference between "traditional" and "cultural" historians. Brennan distinguishes between "traditional historians" - as those studying the past "from a positivist or post-positivist understanding of evidence as elements of reality" (thus the humanities), ${ }^{8}$ and, in contrast, "cultural historians" those from a constructivist or critical theories philosophical orientation (thus sprouting from the social sciences), as also formulated by Hall. ${ }^{9}$

The "humanities historian" is concerned with the study "of unique events or sequences" in order to understand an event by understanding its context, whereas the "social scientist historian" is interested in "general processes", and hopes to construct generalisations and theories "to explain classes of events without regard to space or time". Nord suggests there has been a "convergence of the humanities and the social sciences", 10 and Fourie proposes that the two approaches inevitably must lead to a "fusion of paradigms". ${ }^{11}$ Historiography, in essence, is a combination of the two approaches, as it must use what is to be found through empirical research, and must use what is to be interpreted from those factual findings. This applies to the

6. L. Rabe, "Reflections on Writing about Writing Media History, or, the Mapping of Certain Paradigms and Certain Philosophies in Researching a Media Historiographical Project", Historia, 59, 2 (November 2014), pp 10-27.

7. D.P. Nord, "The Nature of Historical Research", in G. Stempel and B. Westley (eds), Research Methods in Mass Communication (Prentice-Hall, New Jersey, 1989), p 293.

8. $\quad$ B.S. Brennan, Qualitative Research Methods for Media Studies (Routledge, New York and London, 2013), p 94.

9. S. Hall, “Cultural Studies: Two Paradigms”, in T. Bennet et al. (eds), Culture, Ideology and Social Process: A Reader (Open University Press, London, 1981), pp 19-37.

10. Nord, "The Nature of Historical Research", p 294.

11. P.J. Fourie, "Approaches to the Study of Mass Communication", in Fourie (ed.), Media Studies, p 145. 
focus of this study, with the four cartoons being particular (idiographic, from the humanities' view) artefacts subject to the general (nomothetic, social sciences') approach. Particularly as applied to the cartoons under discussion, one should add that history is "more than a list of dates, names and places or facts that speak for themselves", and how those "records of the past" reveal "what people choose to communicate about their world".12

\section{Theoretical departure}

In terms of (media) historiography, this article approaches its subject, namely the four cartoons, from the so-called cyclical theory of history, based on Gawronski's three broad categories in his approach to history, namely the cyclical view, the providential view and the progressive view. ${ }^{13}$

History as a cyclical phenomenon or, simply put, "history repeating itself",14 resonates in what is described as the ancient Greco-Roman cyclical view of history, which, in turn, was echoed in the twentieth century in the "rather pessimistic view" of Spengler, ${ }^{15}$ namely that all "complacent cultures" must go through a specific cycle and unavoidably will not be able to escape a catastrophe. ${ }^{16}$ Or, as Woolf summarised Spengler's notion of the cyclical theory, it suggests "alternating periods of growth and decay". ${ }^{17}$ Woolf also refers to Spengler's "answer" to Vico's "new science" approach,18 namely that it is about the "course nations run" - which can also be applied to the topic of this article, namely the course of South African history as depicted in four cartoons. In this sense, history as a cyclical phenomenon can also be recognised in Berger's theory of "history as a record of progress", 19 - in other words, a continuation of change or as phrased by Oakeshott, as change being "nothing but inherent continuity" (translated), 20 and by Nord as "really [a matter of] continuous variables". ${ }^{21}$ Croce's "celebrated remark", that "all history is contemporary history",

12. Sonderling, "Historical Research in Communication", p 90 (emphasis original).

13. Cited in Sonderling, "Historical Research in Communication", p 92.

14. This phrase does not need any explanation. For example, a search on Google Scholar shows that the phrase has been used up to 6850 times in titles of publications. See https://scholar.google.co.za/scholar?hl=en\&as sdt=0\%2C5\&q=\%22history+ repeating+itself\%22\&btnG $=$, accessed 20 December 2017.

15. Rabe, "Reflections on Writing about Writing Media History."

16. Cited in J. de Villiers, "Geskiedeniswetenskap en die Nuwe Suid-Afrika: Moet die SuidAfrikaanse Geskiedenis Herskryf Word?”, Tydskrif vir Geesteswetenskappe, 52, 2 (2012), p 199.

17. Woolf, A Global History of History, $\mathrm{p} 41$.

18. Vico's "Scienza Nuova" is described as veering between history, philology and sociology (as cited in Woolf, A Global History, pp 294-295). His vision of history "saw little prospect of escape from a recurring sequence of corso e ricorso: though there is 'progress' from one age to another, there is no cumulative and absolute progress".

19. A.A. Berger, Media and Communication Research Methods (Sage, Thousand Oaks, 2011), p 167.

20. As cited in De Villiers, “Geskiedeniswetenskap en die Nuwe Suid-Afrika”, pp 201, 203.

21. Nord, "The Nature of Historical Research", p 293. 
did not mean that "all past events are really present and coeval, but rather that every generation must select and order its past on the basis of the context and circumstances in which it finds itself". ${ }^{22}$

If historiography is thus also interpreted as a "present past",23 one can postulate that, because "views of and theories about people and society continually keep changing, historical interpretations of any given subject also keep changing", as was formulated by Berkhofer. ${ }^{24}$ This is key, because in the case of the focus of this article, one can say that the metaphor of a sunrise depicted in the four cartoons remained the same, but that the context within which each was presented, changed.

Croce postulates that records and documents "only have significance insofar as living humans can reflect upon them and, indeed, relive them" and, conversely, that "we only make sense of life by thinking historically". ${ }^{25}$

One can conclude this discussion with Startt and Sloan's contention that "historical study contains at least three elements: (a) evidence, (b) interpretation, and (c) narrative", ${ }^{26}$ all applicable to the four cartoons under discussion.

\section{Cartoons: A brief history}

Political cartoons are defined as "a special kind of editorial comment", because they are "editorials in pictures". ${ }^{27}$ An editorial is a newspaper or magazine article that provides the editor's opinion, thus the editorial cartoon can be defined as a visual editorial or comment depicting a specific interpretation of events at a time and place according to the view of the editor or proprietor. In some instances, the cartoonist is not part of the editorial team (such as Zapiro), but in others the cartoonist is part of the permanent staff (as was the case with Honiball and Mouton).

According to Verster, cartoons originated in Britain during the early 1800s as political cartoons, printed alongside editorials, hence also the name editorial cartoon. ${ }^{28}$ Yet, another source suggests that cartoons were already published in the eighteenth century as loose prints, while during the nineteenth century magazines such as Punch carried satirical cartoons. ${ }^{29}$ In Britain the first newspaper cartoonist to be appointed on a fulltime basis was Francis Carruthers Gould, to the Pall Mall Gazette in 1888. In the nineteenth century the cartoon became "the most impactful

22. As cited in Woolf, A Global History, $\mathrm{p} 463$.

23. G. Verbeeck, "A New Past for a New Nation? Historiography and Politics in South Africa: A Comparative Approach", Historia, 45, 2, 2000, p 387.

24. As cited in Berger, Media and Communication Research Methods, 156.

25. As cited in Woolf, A Global History, $\mathrm{p} 463$.

26. Cited in S. Lamble, "Documenting the Methodology of Journalism", Australian Journalism Review, 26, 1 (2004), p 97.

27. Franklin et al., Key Concepts in Journalism Studies, p 32.

28. F. Verster, "'n Kultuurhistoriese Ontleding van Pikturale Humor met Besondere Verwysing na die Werk van T.O. Honiball”, DPhil thesis, Stellenbosch, 2003, p 64.

29. Franklin et al., Key Concepts in Journalism Studies, p 32. 
form of printed illustration prior to the regular use of photography".30 A characteristic of cartoonists in particular is said to be that they begin their careers at a very young age ${ }^{31}$ - this is also the case with the cartoonists relevant to this article.

It is generally accepted that the first cartoons with South Africa as subject were published in Britain during the eighteenth and nineteenth centuries. ${ }^{32}$ Press freedom did not exist under either Dutch or British colonial rule at the Cape until 1829.33 The first printed matter was almanacs and notices, and the first newspaper, the Cape Town Gazette and African Advertiser of 16 August 1800, was published as a government gazette. Therefore, the development of cartoons was also limited.

What are regarded as the first political cartoons in South Africa were printed in London, but circulated by The Grahamstown Journal, established in December 1831.34 They were the creations of Frederick l'Ons, and they depicted, in "a venomous, almost libellous way", the relationship between farmers on the colonial border and the governor at the time, Andries Stockenström. The first illustration in a Cape publication was probably in The Cape of Good Hope Literary Gazette, founded in June 1830, comprising a series of seven small woodcut prints and depicting, in the issues of March, April and May 1834, the life of British settlers in the then Albany in a "humorous way". ${ }^{35}$ They were probably drawn by an ex-soldier, Alexander Reid, and were reproduced in 1845-1846 in W.C. Sammons's Sam Sly's African Journal. It is interesting that a South African publication appointed a fulltime cartoonist before one in the UK did so. It was Zingari, or The Zingari, and the cartoonist was C.J.M. Smith. By 1871 Zingari had appointed W.H. Schröder, described as the cartoonist who for the "next twenty years would dominate the art of illustration in South Africa", and who, it was argued, "founded the cartoon" in South Africa. Schröder was only 20 years old in 1871.36

The Cape was "by far" the "most active province" for cartoonists. Around the turn of the previous century, after the South African War, the various political figures of this era were "popular subjects for satirical sketches". ${ }^{37}$ Mason also refers to the "thriving publishing scene" that existed, "especially in the Cape Colony, a century ago". 38 One of the "outstanding satirists" of this era was A.W. Lloyd, also in his twenties, who was later to become famous as the first cartoonist of the Rand Daily

30. J. Watson and A. Hill, Dictionary of Media and Communication Studies (Hodder Arnold, London, 2006), p 34.

31. Franklin et al., Key Concepts in Journalism Studies, p 32.

32. M. Schoonraad and E. Schoonraad, Suid-Afrikaanse Spot- en Strookprentkunstenaars (CUM Boeke, Roodepoort, 1983), p v.

33. J.H.O. du Plessis, “Die Afrikaanse Pers: 'n Studie van die Ontstaan, Ontwikkeling en Rol van die Hollands-Afrikaanse Pers as Sosiale Instelling", PhD thesis, Stellenbosch University, 1943, pp 8-11.

34. Schoonraad and Schoonraad, Suid-Afrikaanse Spot- en Strookprentkunstenaars, p vi.

35. Schoonraad and Schoonraad, Suid-Afrikaanse Spot- en Strookprentkunstenaars, p vi.

36. Schoonraad and Schoonraad, Suid-Afrikaanse Spot- en Strookprentkunstenaars, $\mathrm{p}$ vi.

37. Schoonraad and Schoonraad, Suid-Afrikaanse Spot- en Strookprentkunstenaars, p vii.

38. A. Mason, What's So Funny (Double Storey, Claremont, 2010), p 50. 
Mail and the Sunday Times. ${ }^{39}$ It was indeed Lloyd who was the creator of the first cartoon under discussion in this article. It was used on the front page of the first issue of the Sunday Times on 4 February 1906.

Unlike, for example, the British Cartoon Archive and the Centre for the Study of Cartoons and Caricature, located at the University of Kent, 40 South Africa does not have a centre that supports research specifically into cartoons. Stellenbosch University's Centre for Comic, Illustrative and Book Arts (CCIBA) has a specific focus on comic strips and "is involved in the development, promotion and teaching of the various dimensions of Comic Art, Illustration and Book Art". ${ }^{41}$ In the USA, Ohio State University has a centre for cartoons that uses editorial cartoons to teach history. Named after the "first great American-born cartoonist", Frederick Burr Opper, this socalled Opper Project houses a collection of historic cartoons. ${ }^{42}$

Although a regular number of political cartoon collections are published as annuals every year, a literature search reveals that there are not many publications or studies focusing on political cartoons in South Africa. Two recent publications are Mason's What's So Funny, ${ }^{43}$ and Verster's Die Groot Drie. ${ }^{44}$ The 1983 Afrikaans publication by Schoonraad and Schoonraad,45 reworked and published in 1989 in English (but not yet including a reference to Zapiro), ${ }^{46}$ can be regarded as encyclopaedic up to that point. A small number of academic research works, comprising a number of Master's dissertations and one doctoral thesis, are also available for research in this field. ${ }^{47}$

\section{Cartoons as editorial comment}

Editorial cartoons are described as "graphic expressions of their creator's ideas and opinions", usually reflecting the publication's viewpoint. 48 They are based on current

39. Schoonraad and Schoonraad, Suid-Afrikaanse Spot- en Strookprentkunstenaars, p viii.

40. British Cartoon Archive, nd. http://www.cartoons.ac.uk/, accessed 24 January 2015.

41. Centre for Comic, Illustrative and Book Arts, http://www.cciba.sun.ac.za/ index.php/about-us, accessed 4 January 2017.

42. Opper Project, http://hti.osu.edu/opper, accessed 23 January 2015.

43. Mason, What's So Funny.

44. F. Verster, Die Groot Drie (Penguin, Cape Town, 2015).

45. Schoonraad and Schoonraad, Suid-Afrikaanse Spot- en Strookprentkunstenaars.

46. M. Schoonraad and E. Schoonraad, Companion to South African Cartoonists (Ad. Donker, Johannesburg, 1989).

47. For example, Verster, "'n Kultuurhistoriese Ontleding van Pikturale Humor"; J.W. Conradie, "Editorial Cartoons and Propaganda Posters of the Union of South Africa's Pro-war Press during the First World War, 1914-1918", MA dissertation, Stellenbosch, 2016; F. Verster, "A Critique of the Rape of Justice, with Emphasis on Seven Cartoons by Zapiro (2008-2010)", MA dissertation, Stellenbosch, 2010; and F. Asmal, "Islamophobia and the Media: the Portrayal of Islam since 9/11 and an Analysis of the Danish Cartoon Controversy in South Africa", MA dissertation, Stellenbosch, 2008.

48. Opper Project. 
events and have, "like written editorials", an educational purpose, intended "to make readers think about current political issues". Cartoons use visual and verbal vocabulary that is familiar to readers, and they are used in the mass media, namely newspapers, magazines and on the internet. In printed media, "their size at the time of publication and their placement" (which can be from the front page to the editorial page or the centrefold) affect their impact on readers. The possibility of also using colour, since newsprint is able to print in full colour (as in the case of Figure 6), may "change how readers respond" to the cartoon/s. Cartoons differ from comic strips, as they appear on a newspaper's editorial pages, not on the comics page, and they usually employ a single-panel format and do not feature continuing characters like comic strips do (although the same personalities, e.g., politicians, might be featured continuously). Finally, according to the Opper Project, editorial cartoons are also referred to as political cartoons, because they often deal with political matters. As a "journalistic art form" it has also been described as encapsulating "the heartbeat of a community, their social circumstances and political attitude". 49

Giarelli and Tulman describe cartoons as having "claims to truth, as do other forms of art that attempt to represent and reflect reality", and that "they are a printed record of history as representations of reality that are constructed by the cartoonist". 50 For El Refaie, the political cartoon constitutes "a very specific genre, with its own history, distinctive style, conventions and communicative purposes". 51 She claims that cartoonists rely on widely shared cultural symbols and metaphors, ${ }^{52}$ and argues that "the metaphorical combination of the real and the imaginary" is one of the features of cartoons that distinguish them from other newspaper images. ${ }^{53}$

Cartoons can be analysed according to literary analysis and technical analysis. ${ }^{54}$ A literary analysis refers to the characterisation or non-physical features depicted in a cartoon, its context, humour, irony, metaphor, personification, sarcasm, satire and symbolism. According to Verster, technical analysis consists of analysing body language (e.g., posture or facial expression), characterisation through visual indicators, distortion, exaggeration, composition and style. Typical tools used variously by editorial cartoonists are:

- Caricatures - the drawing of public figures with certain physical features exaggerated;

- Stereotypes - "formulaic images", to represent particular groups;

49. M. Jordaan, "Die Groot Drie: 'n Eeu van Spotprente in Die Burger 1915-2015" ("The Big Three: A Century of Cartoons in Die Burger 1915-2015"), Tydskrif vir Letterkunde Uournal for Literature), 52, 2 (2016), p 194.

50. E. Giarelli and L. Tulman, "Methodological Issues in the Use of Published Cartoons as Data", Qualitative Health Research, 13, 7 (2003), pp 946-947.

51. E. El Refaie, "Multiliteracies: How Readers Interpret Political Cartoons", Visual Communication, 8, 2 (2009), p 184.

52. El Refaie, "Multiliteracies", p 185.

53. El Refaie, "Multiliteracies", p 186.

54. Verster, "A Critique of the Rape of Justice", pp 40-43. 
- Symbols - pictures that traditionally represent something else, such as a dove as a symbol for peace (or, as in this article, a sunrise, depicting a new era);

- Analogies - comparisons suggesting that one thing is similar to something else; and

- Humour - the "power to evoke laughter or to express what is amusing, comical or absurd". 55

Some of the characteristics of editorial cartoons are that they need to combine "clear drawing and good writing", and that they must express a recognisable point of view or opinion. ${ }^{56} \mathrm{~A}$ cartoon "cannot be read or understood by only looking at the words or only looking at the picture"; both must be "read" together to understand the cartoonist's message.

Lastly, not "all editorial cartoons are meant to be funny. Some of the most effective editorial cartoons are not humorous at all."57 That not all cartoons necessarily apply humour or satire is also relevant in terms of the Afrikaans word for cartoon, namely "spotprent" (a "mocking" picture). This term is only applicable to those cartoons that have a humorous or satirical, mocking element, but not those that depict a serious or even solemn event, which is the reason why they have also been described as "tekenprente" ("drawn" pictures), the way Figure 3 has been described,58 or as "mediakuns" (media art) and cartoonists as "mediakunstenaars" (media artists). 59

\section{Metaphor in cartoons}

Regarding the use of metaphors in cartoons, it is understood that "metaphor", "figure of speech" or "symbol" are words or phrases to describe or compare something to something else. A metaphor is therefore a figure of speech in which a word or phrase is applied to an object or action to which it is not literally applicable; or something that is representative or symbolic of something else. It can also be a visual image, as is the case in the cartoons under discussion. A figure of speech, either as word or phrase, literally denotes one kind of object or idea in place of another to suggest a likeness or analogy between them, or is used where an object or activity is treated as a metaphor or symbol. ${ }^{60}$ Again, this can also be applied to a visual image. The same applies to a figure of speech, which can convey meaning or heighten effect, often by comparing or identifying one thing with another that has a meaning or connotation familiar to the reader or listener. A symbol stands for, or suggests, something else. In

55. Opper Project.

56. Opper Project.

57. Opper Project.

58. D.C. de Villiers, "Die Wonderwerk van Agt-en-veertig", in J.P. Scannell (ed.), Keeromstraat 30 (Nasionale Boekhandel Beperk, Cape Town, 1965), p 211.

59. P.J. Cillié, "Voorwoord", in Schoonraad and Schoonraad, Suid-Afrikaanse Spot- en Strookprentkunstenaars, n.p.

60. Merriam-Webster, at www.merriam-webster.com/dictionary/metaphor accessed 26 January 2015. 
the case of the cartoons under discussion, "sunrise" as metaphor is a symbol indicating a new day, or in this case, a new era or a new beginning.

According to Giarelli and Tulman, these "images as metaphor ... facilitate social discourse". ${ }^{61}$ A central point for this discussion is what these authors regard as editorial cartoons which provide a "window into history by showing us what people were thinking and talking about at a given time and place". ${ }^{62}$ For El Refaie, visual metaphor is a common and expected device in political cartoons - in fact, it "is one of the main 'weapons' in the 'cartoonist's armoury'". ${ }^{63}$ However, El Refaie argues that there can be no such thing as a completely "literal" sign, as the process of sign making is always based on a process of analogy. Therefore, "all signs are metaphors". ${ }^{64}$

One of the creators of a cartoon discussed in this study, Jonathan Shapiro (Zapiro), wrote that it is difficult to find "metaphors and scenarios that speak to readers across the board, across cultural and racial divides". For him, the most effective cartoon would be one where the reader understands the metaphors and scenarios used. Although a cartoon takes just a few seconds to read and absorb, "it can have enormous impact and be highly memorable". ${ }^{65}$ Following this discussion of cartoons as editorial comment and the use of metaphor in cartoons, this article will now proceed to present the four cartoons as metaphorical "sunrises" and their creators in chronological order.

\section{An "imperial" sunrise}

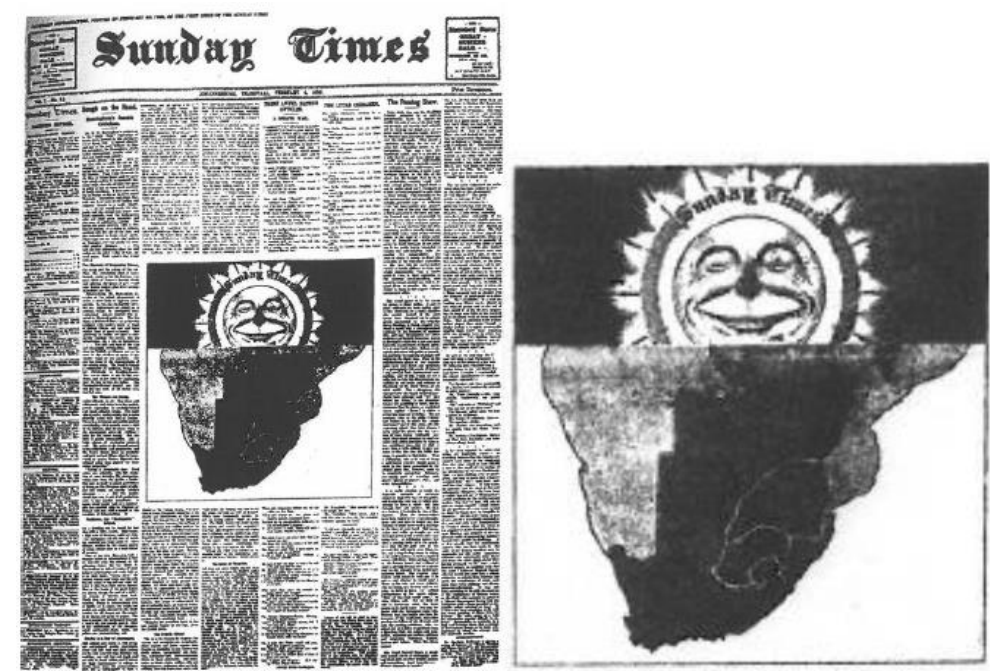

Figure 1: The front page of the first issue of the Sunday Times. ${ }^{66}$

61. Giarelli and Tulman, "Methodological Issues", p 945.

62. Opper Project.

63. E. El Refaie, "Understanding Visual Metaphor: The Example of Newspaper Cartoons", Visual Communication, 2, 1 (2003), p 77.

64. El Refaie, “Understanding Visual Metaphor”, p 82.

65. J. Shapiro, "The Art of Cartooning", in A. Hadland (ed.), Changing the Fourth Estate: Essays on South African Journalism (HSRC Press, Cape Town, 2005), pp 143-144.

66. J. Mervis, The Fourth Estate (Jonathan Ball, Johannesburg, 1989), n.p. 
In the first issue of the Sunday Times, on 4 February 1906, almost a quarter of the front page was assigned to Arthur Lloyd's cartoon (Figure 1). A primary reading of the cartoon might be an innocent depiction of the "sunrise" of the Sunday Times over the sub-continent - an interpretation that is self-evident, given that this first edition is the "sunrise" of a publication titled the Sunday Times. The newspaper's masthead is indeed drawn into the periphery of the dial of a smiling sun, depicting a contented male face that can be described as beaming and full of expectation, given the context.

The Sunday Times was based and distributed mainly in Johannesburg at the time and belonged to mining magnate Sir Abe Bailey, also owner of the Rand Daily Mail, which was established in 1902. What was said of the Mail also applied to the Sunday Times, that it "was really a sort of jingo rag - like most English-language newspapers in this country. ... It was a promotor of colonialism, British jingoism."67

A secondary reading of this cartoon therefore suggests the "rise" of the British Empire and the establishment of a southern African constellation of states. This can be interpreted from the fact that various British southern African colonies, occupied at the time by Britain, are depicted as one entity in the cartoon. Although some borders are indicated, they are still depicted as one territory, coloured in solid black. The dream of British supremacy in southern Africa is thus not only portrayed by the then four political entities in South Africa, but includes what is today Zimbabwe and Zambia, as well as Lesotho, as one region. One can thus interpret this image as a visual manifestation of British supremacy in southern Africa - an empire on which the sun, as was said at the time, would never set (because it occupied territories around the globe). Given the fact that a mining magnate was the owner of the newspaper, one can read another clear message into the cartoon, namely that it is also the sunrise of British imperial capitalism, built on the mineral riches of the colonies, especially the mineral wealth of the Witwatersrand.

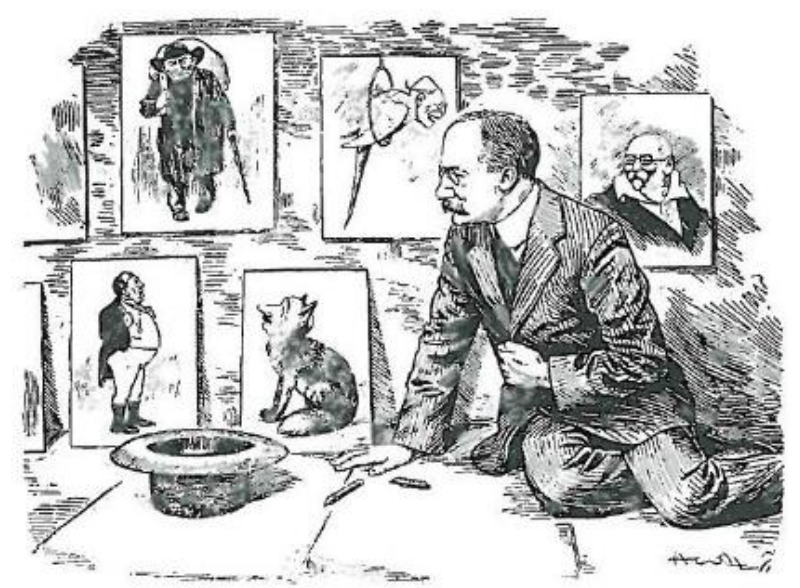

Figure 2: A self-portrait by Lloyd. ${ }^{68}$

67. J. Matisonn, God, Spies and Lies (Missing Ink, Vlaeberg, 2015), p 92.

68. Schoonraad and Schoonraad, Suid-Afrikaanse Spot- en Strookprentkunstenaars, p 139. 
The creator of the cartoon was Arthur Wynell Lloyd (1883-1967) (Figure 2). Lloyd was born in England and studied at Queen's College, Oxford. He arrived in South Africa at the age of 22 in 1905, at the invitation of Sir Abe Bailey, to work as cartoonist for the Rand Daily Mail, and his drawings began to appear from 5 July 1905. According to Schoonraad and Schoonraad, his work showed the influence of British cartoonists he admired, such as Phil May and the already mentioned pioneer Sir Francis Gould, two influential cartoonists at the time. ${ }^{69}$

After the founding of the Sunday Times on 4 February 1906, Lloyd was its chief cartoonist until 1910. He also contributed regularly to The Star. In 1914 he returned to England, where he joined Punch as parliamentary cartoonist. For the following 40 years he contributed to the "English journalistic art". His cartoons were all signed "A.W.L.L.". In the introduction to one of his published collections, Sir Percy Fitzpatrick wrote that Lloyd's cartoons "reflected in inimitable fashion the passing phases of political life and played no mean part in focussing public opinion". ${ }^{70}$

\section{An "Afrikaner nationalist" sunrise}

The second cartoon (Figure 3) was published in Die Burger on 29 May 1948. It depicts a highly recognisable face in the dial of the sunrise, that of D.F. Malan, NP leader at the time of the party's unexpected victory in 1948. He is pictured as the sunrise or new era dawning on South Africa, specifically for the Afrikaner. The setting for this sunrise is a typical South African, almost barren, Karoo landscape. Malan has just a slight, almost shy smile on his face, and is not depicted as looking directly at the viewer, something that can be interpreted either as part of his introvert character, ${ }^{71}$ or the fact that Afrikaners as a nation cannot be described as overly exuberant or demonstrative. The Calvinistic and puritan characteristics of the 1948 Afrikaner would not have welcomed a spontaneous, jovial portrayal. This mirrors Koorts's description of Malan. ${ }^{72}$ The sun's rays form the word "nasionalisme" (nationalism). The cartoon was published in the NP mouthpiece of the time, the Afrikaans, Western Cape daily, Die Burger.

69. Schoonraad and Schoonraad, Suid-Afrikaanse Spot- en Strookprentkunstenaars, p 139.

70. Schoonraad and Schoonraad, Suid-Afrikaanse Spot- en Strookprentkunstenaars, pp 139-140.

71. L. Koorts, D.F. Malan and the Rise of Afrikaner Nationalism (Tafelberg, Cape Town, 2014).

72. Koorts, D.F. Malan and the Rise of Afrikaner Nationalism. 


\section{Het Daghet Overal!}

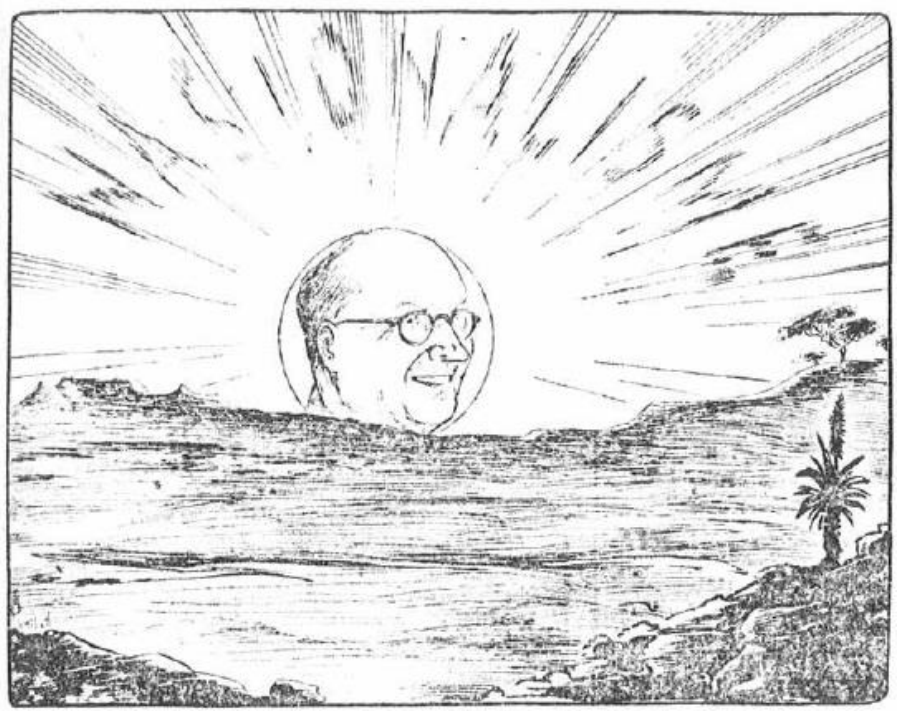

Figure 3: The cartoon depicting the NP victory in 1948.73

(C) Die Burger/Media24)

Almost paradoxical to Malan's facial expression is the execution of the "victorious" sunrays, virtually as a halo around Malan's face. Therefore, an additional part of the reading and interpretation of this cartoon is that the "promise" in the newspaper company's slogan has been fulfilled. This slogan, coined by Nasionale Pers, ${ }^{74}$ which owned Die Burger would have been well known to its readers. "Het daghet overal", meaning the day is breaking, or the sun is rising, was also printed above the cartoon so as to leave no doubt to its meaning for Afrikanerdom. The slogan was chosen for De Nationale Pers Beperkt (the company was initially registered in Dutch) ${ }^{75}$ in 1915 to symbolise hope and to inspire Afrikaners as a people after the economic, cultural and political devastation of the Anglo-Boer War. The logo and slogan of the company can be seen in Figure 4. The cartoon of 1948 thus reflects that the "new dawn" has arrived, and that Afrikaners have reached the ideal of independence, of governing themselves once again. The fact that Malan was the first editor of Die Burger - from its founding in 1915 (as De Burger) to 1924 - is of course also integral to the reading of the cartoon and, in fact, unites or solidifies, the Afrikaner nationalist ideal.

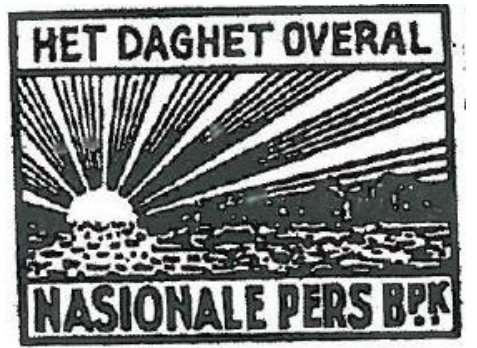

Figure 4: The logo of Nasionale Pers at the time, with the slogan "Het daghet overal" (the day breaks)

73. De Villiers, 'Die Wonderwerk van Agt-en-veertig', p 211.

74. Nasionale Pers, is now Naspers. Die Burger's owner, Media24, is a subsidiary.

75. L. Rabe, "Inleiding", in L. Rabe (ed.), Konstante Revolusie: Naspers, Media24 en Oorgange, (Tafelberg, Cape Town, 2015). 


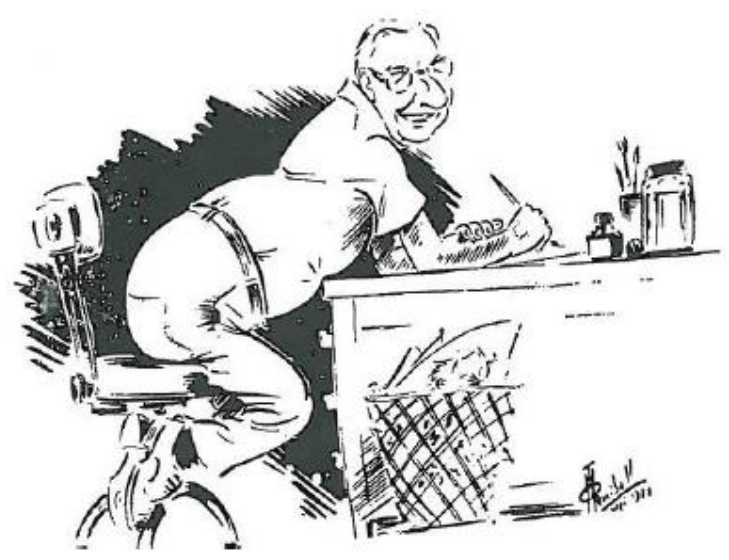

Figure 5: A self-portrait by Honiball. ${ }^{76}$

The creator of the cartoon was T.0. Honiball (1905-1990) (Figure 5), Die Burger's second cartoonist, succeeding D.C. Boonzaier. In 2015, in the paper's centenary year, Honiball became the second of altogether three cartoonists, the third being Fred Mouton (creator of the fourth cartoon under discussion in this article).

Honiball completed his schooling at Stellenbosch Boys' High School (now Paul Roos Gymnasium), where his first drawings appeared in the school's annual. Some of his early work was also used as window decorations in Stellenbosch. He first studied architecture at the University of Cape Town, but after one year went to work as a window decorator in Chicago, where he also attended evening classes in commercial art at the Koester School of Advertising. ${ }^{77}$ He managed to get a job at the Chicago Advertising Agency, where he learnt to incorporate detailed drawing into his work.

In 1930 he returned to Cape Town to take up a position at Napier Advertising. During the depression the firm went bankrupt, and Honiball had to freelance as a commercial artist. His path crossed with that of Naspers when he began to illustrate for its weekly magazine, Huisgenoot. Honiball also designed advertisements during this time. In 1936 he was appointed as fulltime employee and, in 1941, he succeeded Boonzaier. He was instructed to carry on with Boonzaier's style, even with typical characters such as Hoggenheimer, the caricature of capitalism, but soon developed his own style. ${ }^{78}$ Honiball was better known for the cartoon characters of comic strips such as "Oom Kaspaas", "Jakkals en Wolf" and "Adoons-hulle", depicting animal characters in anthropomorphistic ways to symbolise Afrikaner society, and was, according to the Honiball scholar, Verster, not really interested in politics at all, but merely drew what his newspaper editor expected of him. ${ }^{79}$

76. Schoonraad and Schoonraad, Suid-Afrikaanse Spot- en Strookprentkunstenaars, p 98.

77. Schoonraad and Schoonraad, Suid-Afrikaanse Spot- en Strookprentkunstenaars, p 99.

78. Verster, “"n Kultuurhistoriese Ontleding van Pikturale Humor", p 293.

79. Verster, “'n Kultuurhistoriese Ontleding van Pikturale Humor". 


\section{The "African nationalist" sunrise}

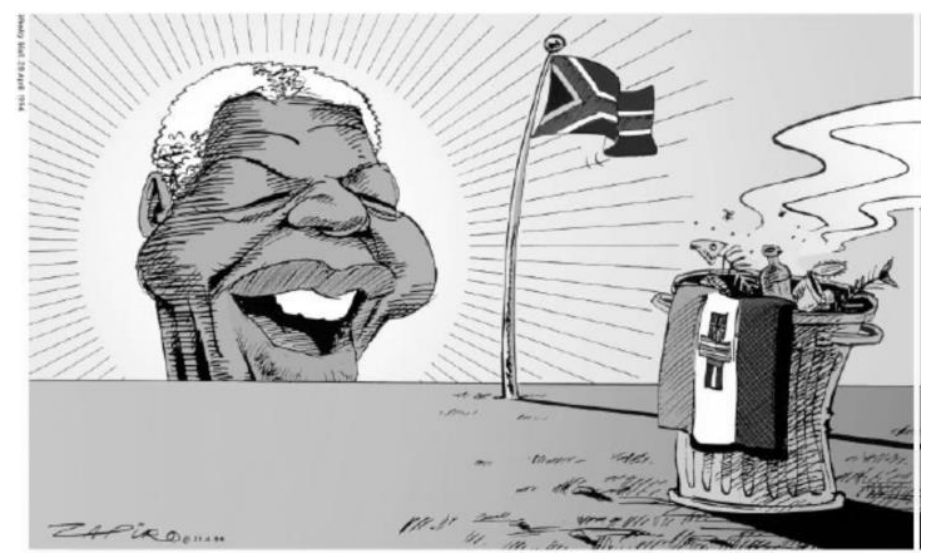

Figure 6: The cartoon depicting the ANC victory. ${ }^{80}$

(C) 1994 Zapiro, reprinted with permission: www.zapiro.com)

The third cartoon (Figure 6) is dated 29 April 1994, in other words two days after the historic first democratic elections in South Africa. The cartoon depicts the beaming, exuberant face of Nelson Mandela, the first democratically elected state president of South Africa, as the face in the sunrise.

The image of an elated "father of the nation", or Madiba, as Mandela also was known, overpowers the other two elements in the cartoon, although the positioning of these two elements indicates their relevance to the occasion. Almost centre stage, in the full light of the new dawn and in a significant (new) breeze, is the new South African flag. In the foreground, to the right, the eye is drawn to a darker corner with reddish, virtually blood-coloured earth, and a rubbish bin with an ominous character. This contrasts with the joyous face of Mandela as metaphor for the sunrise of a "New South Africa" and the idea that the liberation struggle has at last come to an end. The rubbish bin symbolises apartheid South Africa. ${ }^{81}$ Inside the bin, the old South African flag, as symbol of Afrikaner nationalism and its oppressive regime, is now graphically relegated to the dustbin of history, together with rotting fish, a metaphor for the "rotten state" that was left behind after the dawn of the new democratic state.

This cartoon was drawn and printed in colour, with modern print technology now adding other dimensions to the cartoon, including the vibrancy and warmth of Mandela, and a warm, new, all-embracing sunrise.

80. Zapiro, Democrazy: SA's Twenty-year Trip, 1994-2014 (Jacana, Sunnyside, 2014).

81. Since creating the cartoon in Figure 6, Zapiro has used the symbol of the rubbish bin again with regard to the "New" South Africa, when, he drew the towers of the Union Buildings as rubbish bins. See Mason, What's So Funny, p 196. 


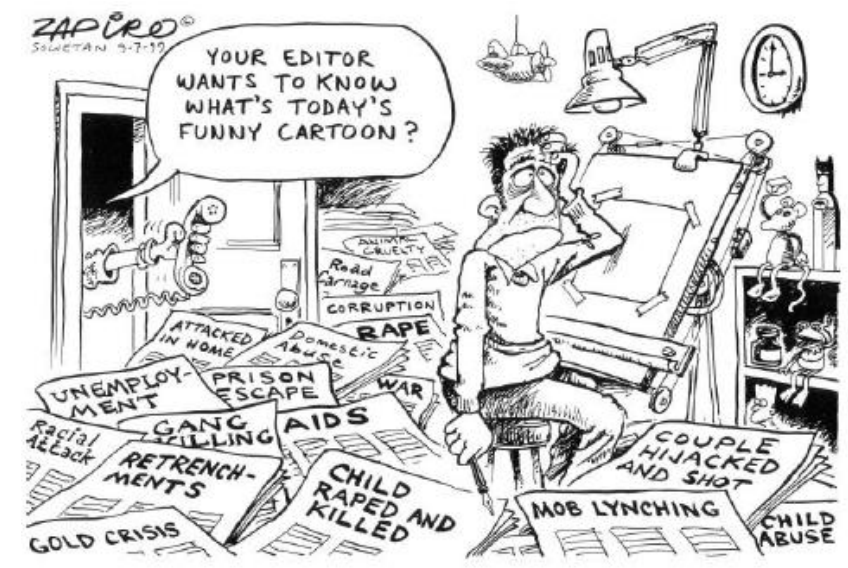

Figure 7: An early self-portrait by Zapiro.

(C 1999 Zapiro, reprinted with permission: www.zapiro.com)

The creator of the cartoon is Zapiro, the pen name adopted by Jonathan Shapiro (born in 1958) (Figure 7). As Zapiro, Shapiro has become "a household name" in South Africa. From "a passionate critic against apartheid" he has evolved into "a zealous critic of all powerful, prominent people across racial boundaries". ${ }^{82}$

Like Honiball, Zapiro studied architecture at the University of Cape Town, but then changed his course to art. In 1986 two of his cartoons were published in the alternative newspaper, the Weekly Mail. He then began to draw for the alternative paper South in 1987, but left on a Fulbright scholarship to study at the School of Visual Arts in New York in 1988. Earlier in 1988 he was detained by the security police after mistakenly being arrested instead of another activist with the same name. After his studies in the US he returned to South Africa in 1990, when he again worked for South and also created political comic strips. In his chapter in a collected work, Zapiro writes that:

... some internationally famous cartoonists go as far as to belittle the notion of doing positive cartoons that are in favour of something. I don't entirely agree with this attitude. In post-apartheid South Africa, with icons like Nelson Mandela and Desmond Tutu, there's a lot to be positive about, even as a cartoonist. ${ }^{83}$

He goes on to explain that he would never see himself "as a praise-singer", but by the same token does not believe that "every cartoon needs to be a political assassination". ${ }^{4}$ The most well-known of all South African cartoonists, Zapiro has received numerous awards, and contributes works for several prominent titles. His work is also re-published in annuals every year.

82. Verster, "A Critique of the Rape of Justice", p 55.

83. Shapiro, "The Art of Cartooning", p 142.

84. Shapiro, "The Art of Cartooning", p 142. 


\section{A “Zuma” sunrise}

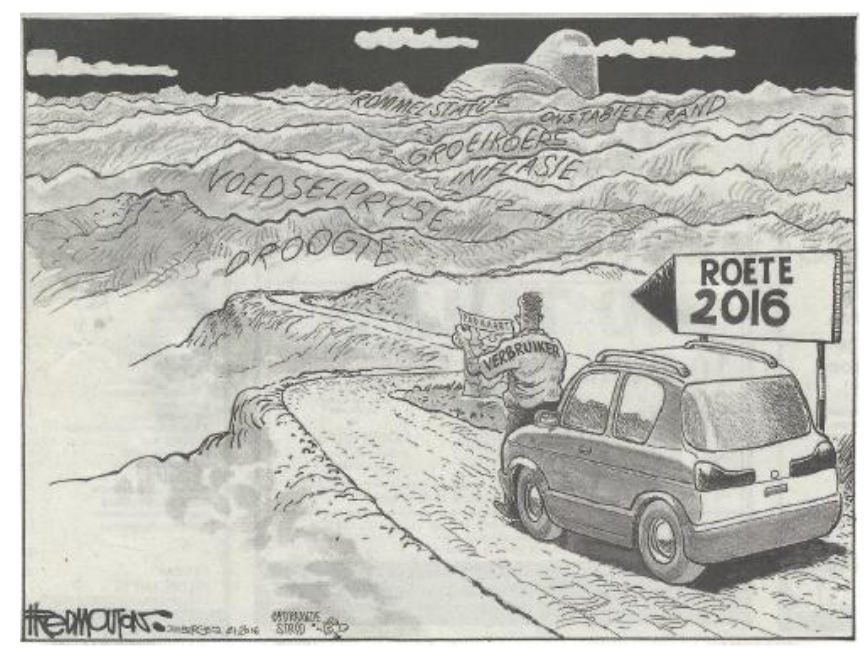

Figure 8: A “Zuma” sunrise, 2 January $2016 .{ }^{85}$

(C) Die Burger/Media24)

The fourth cartoon (Figure 8) is that by Fred Mouton, legendary cartoonist in the Afrikaans media, published in the Cape daily Die Burger's ${ }^{86}$ first edition for 2016 on 2 January. It depicts an ominous landscape, with the hills on the horizon portraying various troublesome issues which threaten to destabilise South Africa. In this depiction, the country is portrayed as the South African consumer, as indicated by the male person reading the road map for the year 2016 .

The "sun", rising in an unpromising pitch-black sky, is recognisable as the head of Jacob Zuma, third president of South Africa. ${ }^{87}$ The doom and gloom of the New Year's expectations are spelled out on the hills along the winding road, such as threatening junk status and an unstable monetary unit. The iconic mouse, commentator in Mouton's cartoons, says an "uphill battle", in line with the ominous hills ahead, is waiting for the South African public in 2016.

It is interesting that the Afrikaans paper - maybe because of its racist past did not use direct accusations against Zuma regarding corruption and state capture issues, but rather indirect accusations. Still, five of the six issues spelled out as being part of an unstable economy can be regarded as the direct result of the financial fiasco called "Nene-gate" which had emerged just a couple of weeks previously, in December 2015, when Zuma sacked the incumbent finance minister, Nhlanhla Nene and

85. F. Mouton, Cartoon in Die Burger, 2 January 2016, p 12.

86. Die Burger has repositioned itself over the period of time since the first democratic election in 1994. Whereas in 1948 it was a party political mouthpiece, the post-94 newspaper and its owner, Media24, a subsidiary of Naspers, now underwrites the principle of media independence from political parties.

87. At the 54th ANC Conference in December 2017, Cyril Ramaphosa was elected as ANC president. 
replaced him with "a little-known back bencher", thereby ushering in "a new political chapter" for South Africa. ${ }^{8}$

One can go even further to claim that this cartoon, appearing on the second day of 2016, was a premonition of a dark future. In fact, 2016 was described as an "annus horribilis" for Zuma, with a number of scandals peaking, such as "Nkandlagate" and "Gupta-gate". ${ }^{89}$ Phrases such as "state capture" and being in contempt of the 1996 Constitution, became synonymous with the president. Consequently, there were calls, even from within his own party, for him to resign and these echoed daily in South African society.
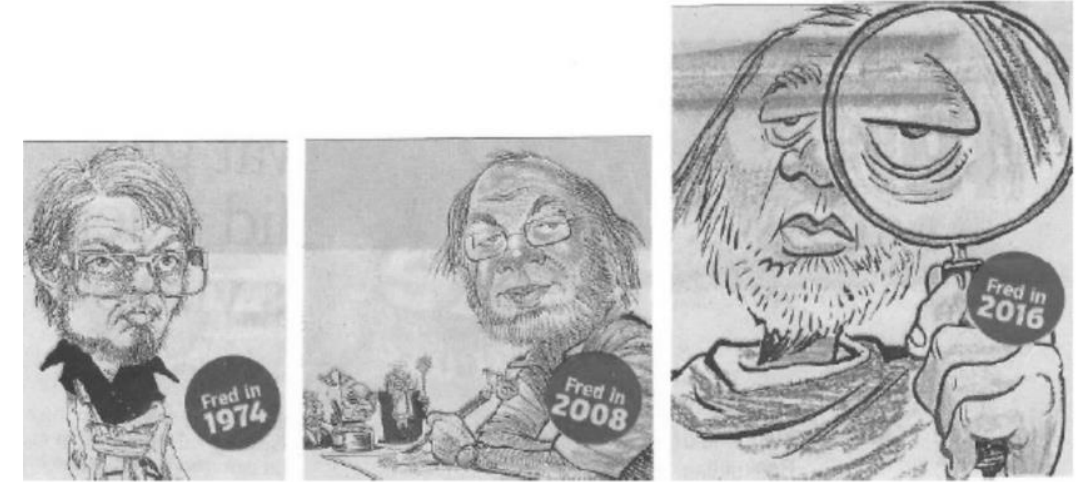

Figure 9: Three self-portraits by Mouton, dated 1974, 2008 and $2016 . .^{90}$

(C) Fred Mouton)

The creator of the cartoon is Fred Mouton (born in 1947) (Figure 9). Mouton can be regarded as being just as famous in the Afrikaans media as Zapiro is in the English media. He succeeded Honiball as Die Burger's third cartoonist in January 1975. ${ }^{91}$ Mouton studied graphic art at the then Cape Technical College (now Cape Peninsula University of Technology). While still a student, some of his illustrations were published in Fair Lady. ${ }^{92}$

As the third of Die Burger's three cartoonists over one century, Mouton, like Honiball, cannot be described as being interested in politics - unlike Boonzaier, who was a staunch Afrikaner and a Nationalist. ${ }^{93}$ Nevertheless both these cartoonists had to execute their cartoons according to the editorial policy of their paper. Indeed, the editor at the time of Mouton's appointment, was well known for the fact that he prescribed to Mouton exactly what to draw, although the editor chose to call this

88. J. Battersby, "Jacob Zuma's Greatest Blunder", Fin24, http://www.fin24.com/ BizNews/brilliant-john-battersby-unpacks-nenegate-jacob-zumas-greatest-blunder20151224, accessed 4 January 2017.

89. M. du Preez, in "Max du Preez: 2016 was 'n Riller, Sepie en Tranetrekker", M. la Vita, Netwerk24, http://www.netwerk24.com/Stemme/Aktueel/max-du-preez-2016-wasn-riller-sepie-en-tranetrekker-20161220, accessed 29 December 2016.

90. F. Mouton, three self-portraits, Die Burger, 22 December 2016, p 8.

91. Verster, Die Groot Drie, p 141.

92. Verster, Die Groot Drie, p 141.

93. Mason, What's So Funny, p 52. 
"collaborating" with the artist. At the same time he also kept "a close eye on the artist's implementation of his idea, until he was fully satisfied with the final result". ${ }^{4}$ In other words, Mouton was obliged to follow a conservative editorial policy well after democratisation.

Esterhuyse provides a discussion on how the Afrikaans media, for example contributed to vilifying the Truth and Reconciliation Commission (TRC) and its hearings in 1997 through, inter alia, cartoons. In the process, this arm of the media went so far as demonising and ridiculing Archbishop Desmond Tutu. ${ }^{95}$ One can thus state that the cartoons by Mouton during this period were "more often than not a depiction of ideas provided to him by his editor". As it was described, all "too often, the 'collaboration' required of Afrikaans cartoonists ... meant submitting to strict, if not authoritarian, editorial control". 96

Nevertheless, Mouton's artistic talent is indisputable, and since the liberation of the Afrikaans media from toeing the party line he truly became a supreme social commentator. He can, indeed be described as being "volksbesit" (public property, or idiomatically, a "national treasure") - knowing his market exceptionally well and being a maestro in depicting the joys, trials and tribulations of every aspect of the "New" South Africa. Indeed, he does this so well that art historian Hans Fransen describes him as the "Rembrandt of South African cartoonists" because of his exemplary artistic renditions. ${ }^{97}$ One can claim that despite having to draw, for example, Tutu as the "devil" during the TRC hearings, his work is can be described as "piercing, satirical - the lampooner without vindictiveness". 98

\section{Conclusion}

Zapiro himself wrote, as stated earlier, that it is difficult to find metaphors and scenarios that speak to readers across cultural and racial divides, although the most effective cartoon would be one where the reader understood the metaphors and scenarios used. The cartoon, while taking "just a few seconds to read and absorb" and "can have enormous impact and be highly memorable". 99 One can say that all these elements apply to all four cartoons under discussion. A simple analysis may even suffice, namely that the reader could immediately understand the messages conveyed and, importantly, that all four of these "sunrises", although applying the same metaphor, symbolised significant new, and different eras dawning in South Africa.

The metaphor of a "new dawn" in each of the four cartoons represented a "dawning": whether the dawn of a new newspaper with the title "sun" as part of its

94. Mason, What's So Funny, p 52.

95. W. Esterhuyse, "TRC Cartoons and the Afrikaner Community", in W. Verwoerd and M. Mabizela (eds), Truths Drawn in Jest (David Philip, Cape Town, 2000), pp 63-76.

96. Mason, What's So Funny, p 52.

97. Verster, Die Groot Drie, p 144.

98. Schoonraad and Schoonraad, Companion to South African Cartoonists.

99. Shapiro, "The Art of Cartooning", pp 143-144. 
masthead, along with its subsequent readings; the "dawn" of the political era of legalised segregation called apartheid; the dawn of a democratic era under the iconic Mandela; or the "dawn" of a dark future under the Zuma presidency.

These four cartoons, the first in 1906 and last in 2016, also illustrate how (media) historiography draws on both the humanities and the social sciences (the idiographic, or particularising, as well as the nomothetic, or generalising), because these cartoons - as artefacts of the past - represent certain events and depict different "sunrises" as symbolic of different status quos. As a "unique event", or "sequence of events", they can be understood from a humanities point of view in a particular space and time, whereas as "general processes", from the social sciences' point of view, they can be understood "to explain classes of events without regard to space or time". 100

Simultaneously, the idea of change as a paradox, incorporating both the element of transformation as well as the inclination to remain the same,101 is applicable to these four sunrise metaphors. Indeed, as explained above: change in fact is "nothing but inherent continuity", or "really [a matter of] continuous variables". ${ }^{102}$ One can thus conclude that the "change" that occurred in South Africa from 1906 to 2016 was nothing more than inherent continuity as portrayed by the four "sunrises", although each symbolised a different political era.

Essentially, the cyclical view of history, the "circle of historical research", remains ever open and ever widening - an eternal cycle, in fact - as cyclical as life itself. Indeed, it is apt to conclude with a quote by Mary Ann Evans (known as George Eliot): "History, we know, is apt to repeat itself, and to foist very old incidents upon us with only a slight change of costume".103

Finally, the purpose of this article was also to add to South African (media) history, as well as to supplement an even bigger lacuna, namely that of cartoon studies as source of history, indeed, also to stimulate and inspire cartoon studies from within such a (media) historiographical framework, exploring a rich South African treasure trove of cartoons and cartoonists.

\section{REFERENCES}

Asmal, F., "Islamophobia and the Media: The Portrayal of Islam since 9/11 and an Analysis of the Danish Cartoon Controversy in South Africa", MA dissertation, Stellenbosch University, 2008.

100. Nord, "The Nature of Historical Research", pp 293-294.

101. Oakeshott, cited in De Villiers, "Geskiedeniswetenskap en die Nuwe Suid-Afrika“, pp 201-203.

102. Nord, "The Nature of Historical Research", p 293.

103. G. Eliot, Scenes of Clerical Life (1857) http://www.online-literature.com/ george eliot/ scenes-of-clerical-life/43/, accessed 19 February 2015. 
Battersby, J., “Jacob Zuma's Greatest Blunder”, Fin24, http://www. fin24.com/BizNews/brilliant-john-battersby-unpacks-nenegate-jacob-zumasgreatest-blunder-20151224, accessed 4 January 2017.

Berger, A.A., Media and Communication Research Methods (Sage, Thousand Oaks, 2011).

Brennan, B.S., Qualitative Research Methods for Media Studies (Routledge, New York and London, 2013).

British Cartoon Archive. nd. http://www.cartoons.ac.uk/, accessed 24 January 2015.

Centre for Comic, Illustrative and Book Arts, http://www.cciba.sun.ac.za/ index.php/about-us, accessed 4 January 2017.

Cillié, P.J., "Voorwoord", in Schoonraad, M. and Schoonraad E. (eds), Suid-Afrikaanse Spot- en Strookprentkunstenaars, (CUM Boeke, Roodepoort, 1983).

Conradie, J.W., "Editorial Cartoons and Propaganda Posters of the Union of South Africa's Pro-war Press during WWI", MA dissertation, Stellenbosch, 2016.

De Villiers, D.C., "Die Wonderwerk van Agt-en-veertig", in Scannell, J.P. (ed.), Keeromstraat 30 (Nasionale Boekhandel Beperk, Cape Town, 1965).

De Villiers, J., "Geskiedeniswetenskap en die Nuwe Suid-Afrika": Moet die SuidAfrikaanse Geskiedenis Herskryf Word?", Tydskrif vir Geesteswetenskappe, 52, 2 (2012).

Du Plessis, J.H.O., “Die Afrikaanse Pers: 'n Studie van die Ontstaan, Ontwikkeling en Rol van die Hollands-Afrikaanse Pers as Sosiale Instelling", PhD thesis, 1943.

El Refaie, E., "Multiliteracies: How Readers Interpret Political Cartoons”, Visual Communication, 8, 2 (2009).

El Refaie, E., "Understanding Visual Metaphor: The Example of Newspaper Cartoons", Visual Communication, 2, 1 (2003).

G. Eliot, Scenes of Clerical Life (1857). http://www.online-literature. com/george eliot/scenes-of-clerical-life/43/, accessed 19 February 2015.

Esterhuyse, W., "TRC Cartoons and the Afrikaner Community," in Verwoerd W. and Mabizela M. (eds), Truths Drawn in Jest (David Philip, Cape Town, 2000).

Fourie, P.J., "Approaches to the Study of Mass Communication", in Fourie P.J. (ed.), Media Studies: Media History, Media and Society (Juta, Kenilworth, 2007).

Franklin, B., Hamer, M., Hanna, M., Kinsey M. and Richardson, J.E., Key Concepts in Journalism Studies (Sage, London, Thousand Oaks and New Delhi, 2005).

Giarelli, E. and Tulman, L., "Methodological Issues in the Use of Published Cartoons as Data", Qualitative Health Research, 13, 7, 2003.

Hall, S., "Cultural Studies: Two Paradigms”, in Bennet T. et al. (eds), Culture, Ideology and Social Process: A Reader (Open University Press, London, 1981).

Jordaan, M., "Die Groot Drie: 'n Eeu van Spotprente in Die Burger 1915-2015", Tydskrif vir Letterkunde, 52, 2 (2016).

Koorts, L., DF Malan and the Rise of Afrikaner Nationalism (Tafelberg, Cape Town, 2014).

La Vita, M., "Max du Preez: 2016 was 'n Riller, Sepie en Tranetrekker”, Netwerk24, http://www.netwerk24.com/Stemme/Aktueel/max-du-preez-2016-was-nriller sepie-en-tranetrekker-20161220, accessed 29 December 2016.

Lamble, S., "Documenting the Methodology of Journalism", Australian Journalism Review, 26, 1 (2004).

Mason, A., What's So Funny (Double Storey, Claremont, 2010). 
J. Matisonn, God, Spies and Lies (Missing Ink, Vlaeberg, 2015).

Merriam-Webster, www.merriam-webster.com/dictionary/metaphor accessed 26 January 2015.

Mervis, J., The Fourth Estate (Jonathan Ball, Johannesburg, 1989).

Mouton, F., Cartoon in Die Burger, 2 January 2016.

Mouton, F., Three Self-Portraits, Die Burger, 22 December 2016

Nord, D.P., "The Nature of Historical Research", in Stempel, G. and Westley B. (eds), Research Methods in Mass Communication (Prentice-Hall, New Jersey, 1989).

Opper Project, http://hti.osu.edu/opper, accessed 23 January 2015.

Rabe, L., "Reflections on Writing about Writing Media History, or, the Mapping of Certain Paradigms and Certain Philosophies in Researching a Media Historiographical Project”, Historia, 59, 2 (November 2014).

Rabe, L., "Inleiding", in Rabe, L. (ed), Konstante Revolusie: Naspers, Media24 en Oorgange (Tafelberg, Cape Town, 2015).

Schoonraad, M. and Schoonraad, E. (eds), Suid-Afrikaanse Spot- en Strookprentkunstenaars (CUM Boeke, Roodepoort, 1983).

Schoonraad, M. and Schoonraad, E., Companion to South African Cartoonists (Ad. Donker, Johannesburg, 1989).

Shapiro, J., "The Art of Cartooning", in A. Hadland (ed.), Changing the Fourth Estate: Essays on South African Journalism (HSRC Press, Cape Town, 2005).

Sonderling, S., "Historical Research in Communication", in Du Plooy, G.M. (ed.), Introduction to Communication (Juta, Cape Town, 1995).

Verbeeck, G., "A New Past for a New Nation? Historiography and Politics in South Africa: A Comparative Approach", Historia, 45, 2 (2000).

Verster, F., "'n Kultuurhistoriese Ontleding van Pikturale Humor met Besondere Verwysing na die Werk van T.O. Honiball”, DPhil thesis, Stellenbosch, 2003.

Verster, F. "A Critique of the Rape of Justice, with Emphasis on Seven Cartoons by Zapiro (2008-2010)", Master's thesis, Stellenbosch University, 2010.

Verster, F., Die Groot Drie (Penguin, Cape Town, 2015).

Watson J. and Hill, A., Dictionary of Media and Communication Studies (Hodder Arnold, London, 2006).

Wigston, D., “A History of South African Media”, in Fourie, P.J. (ed.), Media Studies, Media History, Media and Society (Juta, Cape Town, 2007).

Woolf, D., A Global History of History (Cambridge University Press, New York, 2011). Zapiro, Democrazy: SA's Twenty-year Trip, 1994-2014 (Jacana, Sunnyside, 2014). 